\title{
Fatty Acid Composition of Mixed-Rumen Bacteria: Effect of Concentration and Type of Forage
}

\author{
P. Bas, ${ }^{*}$ H. Archimède,† A. Rouzeau, ${ }^{*}$ and D. Sauvant* \\ *UMR de Physiologie de la Nutrition et Alimentation, \\ INRA-INAPG, 16 rue Claude Bernard, \\ 75231 Paris Cedex 05, France \\ †Station de Recherches Zootechniques, INRA, BP 1232, \\ 97185 Pointe à Pitre Cedex, France
}

\section{ABSTRACT}

The effects of concentration and type of forage in the diet on lipid content and fatty acid (FA) composition of rumen bacteria were studied in 14 goats fitted with duodenal cannulas. The goats were fed a complete maintenance diet containing 40,70 , or $100 \%$ chopped forage (dry matter basis) in two equal meals. Forage was either corn stover or alfalfa hay. Microbial cell matter (MCM) was isolated by differential centrifugation of duodenal contents. The FA content of the MCM varied from 5 to $11 \%$ of $\mathrm{DM}$ and decreased with forage level in the diet. Main FA in MCM were $\mathrm{C}_{18: 0}$ and $\mathrm{C}_{16: 0}$ : together they accounted for $70 \%$ of total FA in MCM. The mono-unsaturated FA and branched-chain FA (isoFA and anteiso-FA) each represented about $10 \%$ of FA by weight. The proportion of even-chain saturated FA decreased and those of odd- and branched-chain FA increased with increasing forage. With the corn stoverbased diet even-chain saturated FA were lower than with the alfalfa hay-based diet, whereas the unsaturated FA, odd-chain FA, and branched-chain FA were higher. The neutral detergent fiber content of the diet seemed to explain most of the variation associated with even-chain saturated FA, and odd- and branched-chain FA. Our results suggest that, for diets not supplemented with fat, mixed rumen bacteria accumulated energy reserves, by increasing synthesis of either evenchain saturated FA, or saturated odd-chain FA and saturated branched-chain FA.

(Key words: fatty acid, forage, goat, rumen bacteria)

Abbreviation key: $\mathbf{A H}=$ alfalfa hay, $\mathbf{C S}=$ corn stover, $\mathbf{E C L}=$ equivalent chain-length, $\mathbf{F A}=$ fatty acid, $\mathbf{L F}=$ forage level, $\mathbf{L I}=$ lipid extract, $\mathbf{M C M}=$ microbial cell matter.

Received November 25, 2002.

Accepted March 3, 2003.

Corresponding author: P.Bas; e-mail: bas@inapg.inra.fr.

\section{INTRODUCTION}

Rumen microbial matter is an important source of nutrients for the host animal (Demeyer and Doreau, 1999). Numerous characteristics of the diet can influence the synthesis and composition of the microbial cell matter (MCM). Interest in MCM to date has mainly focused on aspects of nitrogen and carbohydrate metabolism, although fatty acid content and composition of rumen microbes has also been studied (Moore and Christie, 1984; Harfoot and Hazlewood, 1997). Newly synthesized fatty acids (FA) enabled a positive ruminal FA balance with low-lipid diets (Sauvant and Bas, 2001).

The FA composition of rumen bacteria is characterized by a large proportion of branched-chain FA (Minato et al., 1988; Kaneda, 1991; Bae et al., 2000). Branchedchain FA of bacterial origin can make up 1 to $3 \%$ of carcass lipids (Duncan and Garton, 1978; Bas and Morand-Fehr, 2000) and milk lipids (Parodi, 1977; Alonso et al., 1999) in ruminants. There is now renewed interest in the FA composition of ruminant products (Kalscheur et al., 1997a, 1997b; Stanton et al., 1997; Kelly et al., 1998; Parodi, 1999), particularly for transFA and conjugated linoleic acid, in which rumen microbes are assumed to play a key role. Odd-chain and branched-chain FA in meat and milk have been considered tools for characterizing rumen bacterial populations (Dewhurst et al., 2000, 2002; Vlaeminck et al., 2002). Previous studies often utilized diets supplemented with lipids (Bauchart et al., 1990; Weisbjerg et al., 1992) and rarely diets not supplemented with fat. Very few published studies of the effects of dietary fiber on the composition of ruminal bacteria lipids exist (Vlaeminck et al., 2002). Our aim was, first, to evaluate the effects of forage:concentrate ratios, and of source of forage, on FA content and composition of rumen microbes with diets having low fat contents. Secondly, to improve our understanding of variation in the composition and synthesis of ruminal bacteria lipids, the effect of diet chemical composition was examined. 
Table 1. Chemical composition of feeds ${ }^{1}$.

\begin{tabular}{|c|c|c|c|c|c|}
\hline \multirow[b]{2}{*}{ Feeds } & \multicolumn{2}{|c|}{ Forages } & \multicolumn{3}{|c|}{ Concentrates } \\
\hline & $\mathrm{AH}$ & $\mathrm{CS}$ & FS & SS & $\mathrm{DF}$ \\
\hline \multicolumn{6}{|c|}{ Concentrate composition, \% of DM } \\
\hline Wheat & & & 24 & & \\
\hline Barley & & & 24 & & \\
\hline Oat & & & 24 & & \\
\hline Corn & & & & 52 & \\
\hline Sorghum & & & & 20 & \\
\hline Soybean hulls & & & & & 39 \\
\hline Gluten feed & & & & & 19 \\
\hline Beet pulp & & & & & 14 \\
\hline Soybean meal & & & 10 & 10 & 10 \\
\hline Coconut meal & & & & 10 & 10 \\
\hline Green peas & & & 10 & & \\
\hline Molasses & & & 5 & 5 & 5 \\
\hline Mineral and vitamin mixture & & & 3 & 3 & 3 \\
\hline \multicolumn{6}{|l|}{ Chemical composition, \% of DM } \\
\hline $\mathrm{OM}$ & 93.1 & 90.5 & 93.4 & 93.4 & 90.0 \\
\hline $\mathrm{CP}$ & 16.9 & 4.4 & 18.1 & 16.9 & 21.3 \\
\hline $\mathrm{NDF}$ & 55.3 & 77.6 & 20.7 & 21.5 & 41.5 \\
\hline $\mathrm{ADF}$ & 36.5 & 43.7 & 7.0 & 7.0 & 22.5 \\
\hline ADL & 8.5 & 3.6 & 0.8 & 1.3 & 1.7 \\
\hline FA & 1.7 & 1.9 & 1.8 & 1.4 & 1.2 \\
\hline
\end{tabular}

\section{MATERIALS AND METHODS}

\section{Animals and Diets}

Fourteen dry goats, cannulated at the proximal duodenum, received mixed rations in two equal meals per day (at 0800 and $1700 \mathrm{~h}$ ). The 14 diets were 40:60, 70:30, or 100:0 forage:concentrate on a DM basis. Two types of chopped forages were tested: alfalfa hay (AH) and corn stover silage (CS). Three types of concentrates were used. The composition of forages and concentrates is given in Table 1 . The trial was an incomplete Latin square design ( 14 goats $\times 14$ diets $\times 4$ periods). During the four experimental periods of 4 -wk duration, the 14 diets were distributed to the 14 goats so that at the end of the trial each diet was given to four different goats. At the end of each experimental period, a representative sample of duodenal digesta was constituted from 12 subsamples per goat. Subsamples were removed during 3 consecutive days, $6 \mathrm{~h}$ apart (at $0,6,12,18,2,8,14$, $20,4,10,16$ and $22 \mathrm{~h}$, after the morning feeding). For each experimental period, the 12 duodenal subsamples harvested per goat were pooled and freeze-dried. Samples from the four experimental periods were then pooled by diet. Animal management and experimental protocol were performed with respect to animal care and welfare. All management practices for the goats (e.g., operative procedure and housing conditions) were previously reported (Archimède et al., 1995).

\section{Measurements}

Samples were filtered through a gauze (1-mm mesh), pooled for each goat, and then frozen. The microbial fraction was obtained from duodenal fluid by differential centrifugation. The samples were first heated up to $39^{\circ} \mathrm{C}$ for $2 \mathrm{~h}$ and centrifuged $\left(500 \times g\right.$ for $30 \mathrm{~min}$ at $4^{\circ} \mathrm{C}$ ) to remove protozoa and feed particles. The supernatant and the washing solution of the pellets were treated according to the method of Legay-Carmier and Bauchart (1989). The pooled residues from the second centrifugation $\left(27,000 \times g\right.$ for $30 \mathrm{~min}$ at $\left.4^{\circ} \mathrm{C}\right)$ constituted the MCM.

Nitrogen and lipid contents were measured on lyophilized pooled residues. Bacterial lipids were extracted twice with chloroform:methanol $(2 / 1, \mathrm{vol} / \mathrm{vol})$ and then by ethanol: $6 \mathrm{~N} \mathrm{HCl}$ :chloroform (1/1/2/, vol/vol/vol). The lipid extract (LI) was purified by saponification with $15 \mathrm{ml}$ of $2 \mathrm{~N}$ potassium hydroxide solution in $95 \%$ etha$\mathrm{nol}(\mathrm{vol} / \mathrm{vol})$. The FA were released with $15 \mathrm{ml}$ of $6 \mathrm{~N}$ $\mathrm{HCl}$ and then extracted three times with $30 \mathrm{ml}$ of hexane. The FA were methylated at $70^{\circ} \mathrm{C}$ with a methanolic boron trifluoride solution (14\%, wt/vol; $1.5 \mathrm{ml}$ of solution per $20 \mathrm{mg}$ of dry FA sample). Esters were separated twice by gas-liquid chromatography (Varian 3400-CX, Les Ulis, France) on a DB-wax fused silica capillary column $(60-\mathrm{m} \times 0.25-\mathrm{mm}$ i.d. $\times 0.25-\mu \mathrm{m}$ film thickness: JW, Folsom, CA), either by GLC equipped with a flameionization detector held at $220^{\circ} \mathrm{C}$ or by GLC-MS. The 
BAS ET AL.

Table 2. Chemical composition of the microbial cell mass (percentage of DM).

\begin{tabular}{|c|c|c|c|c|c|c|c|c|c|c|}
\hline \multirow{2}{*}{$\frac{\text { Forage }^{1}}{\mathrm{LF}^{2}}$} & \multicolumn{3}{|c|}{$\mathrm{AH}$} & \multicolumn{3}{|c|}{ CS } & \multirow[b]{2}{*}{ SEM } & \multicolumn{3}{|c|}{ Effect, $P$-value ${ }^{3}$} \\
\hline & 40 & 70 & 100 & 40 & 70 & 100 & & $\mathrm{~F}$ & $\mathrm{LF}$ & $\mathrm{F}^{*} \mathrm{LF}$ \\
\hline \multicolumn{11}{|l|}{ Item } \\
\hline $\mathrm{LI}^{4}$ & $19.7^{\mathrm{a}}$ & $16.4^{\mathrm{ab}}$ & $14.2^{\mathrm{bc}}$ & $15.7^{\mathrm{b}}$ & $11.2^{\mathrm{c}}$ & $10.2^{\mathrm{c}}$ & 0.52 & 0.006 & 0.009 & 0.85 \\
\hline $\mathrm{FA}^{4}$ & $11.3^{\mathrm{a}}$ & $8.7^{\mathrm{b}}$ & $7.0^{\mathrm{bc}}$ & $9.5^{\mathrm{ab}}$ & $6.2^{\mathrm{c}}$ & $5.2^{\mathrm{c}}$ & 0.34 & 0.03 & 0.003 & 0.87 \\
\hline $\mathrm{N}$ & 6.2 & 6.4 & 6.4 & 6.0 & 6.4 & 5.5 & 0.13 & 0.24 & 0.38 & 0.57 \\
\hline
\end{tabular}

a,b,c Means within a row lacking a common superscript differ $(P<0.05)$.

${ }^{1} \mathrm{AH}=$ alfalfa hay, and CS: Corn stover silage.

${ }^{2} \mathrm{LF}=$ level of forage (40,70, or $\left.100 \%\right)$.

${ }^{3} \mathrm{~F}=$ effect of type of forage (AH vs. CS), LF = effect of level of forage (40,70, or 100\%), and $\mathrm{F}^{*} \mathrm{LF}=$ interaction between $\mathrm{F}$ and $\mathrm{LF}$.

${ }^{4} \mathrm{LI}=$ lipid extract, $\mathrm{FA}=$ fatty acids.

split ratio in the injector $\left(230^{\circ} \mathrm{C}\right)$ was $30: 1$. Oven temperature was programmed to increase from 120 to $195^{\circ} \mathrm{C}$ at a rate of $4^{\circ} \mathrm{C} / \mathrm{min}$ and was then maintained at $195^{\circ} \mathrm{C}$ for $60 \mathrm{~min}$. Column flow was $0.95 \mathrm{ml} / \mathrm{min}$ of He. For the GLC-MS procedure, chromatographic conditions were similar to those of the first one but the chromatograph was equipped with an ion-trap detector (Finnigan Mat, ITD 800, Orsay, France). The FA were further identified from equivalent chain-length (ECL) (Miwa et al., 1960) determined by interpolation between two consecutive even-straight-chain saturated FA and compared by reference to standards (Sigma, St. Louis, MO; Interchim, Montluçon, France) analyzed under similar conditions and from mass spectra obtained by electron-impact. Except for FA content, the chemical analysis of the feeds has already been presented by Archimède et al. (1995).

Statistical analyses were performed with the general linear models procedure of SAS (SAS, 1987). Concentrate effects were not significant and were pooled with the residual. Thus, the effects of forage type and forage level (LF) were tested in a two-way unbalanced factorial arrangement with three observations per cell for diets with 40:60 and 70:30 forage:concentrate ratios, and one observation per cell for the 100:0 forage:concentrate ratio diet. Consequently, hypotheses were tested using type III SS sums of squares. The model used was:

$$
Y_{i j k}=\mu+F_{i}+L F_{j}+F_{i} \times L F_{j}+e_{i j k}
$$

with 14 total observations and where $\mu=$ the overall mean, $F_{i}=$ type of forage (AH vs. CS, $1 \mathrm{df}$ ), $\mathrm{LF}_{\mathrm{j}}=$ level of forage, $(40,70$, or $100 \%, 2 \mathrm{df}), \mathrm{F}_{\mathrm{i}} \times \mathrm{LF}_{\mathrm{j}}=$ the interaction between $\mathrm{F}$ and $\mathrm{LF}(2 \mathrm{df})$, and $\mathrm{e}_{\mathrm{ijk}}=$ the residual variation. Comparisons with $P<0.05$ were considered significant.

\section{RESULTS}

\section{Chemical Composition of Bacterial Extracts}

The LI and FA contents of the MCM were $15.3 \pm$ $1.0 \%$, and $8.5 \pm 0.6 \%$ (mean $\pm \mathrm{SE}$ ), and ranged from 10.2 to 20.2 and 5.2 to $12.5 \%$ of DM, respectively (Table 2). There was a close relationship between the two data sets [FA $=0.56 \mathrm{LI}, \mathrm{n}=14, \mathrm{r}^{2}=0.99$, residual standard deviation $(\mathrm{RSD})=0.9 \%$ of $\mathrm{DM}]$. The $\mathrm{N}$ content of the MCM was less variable than the LI or FA contents (N $=6.2 \pm 0.12 \%$ of $\mathrm{DM})$. The LI and FA contents were negatively correlated with the dietary $\mathrm{LF}(\mathrm{r}=-0.61, P$ $<0.05$, and $\mathrm{r}=-0.74, P<0.01$, for LI and FA, respectively), and with NDF and ADF diet contents $(\mathrm{r}=-0.86$, $P<0.01$, and $\mathrm{r}=-0.83, P<0.01$, between NDF and LI and FA, respectively; and $\mathrm{r}=-0.79, P<0.01$, and $\mathrm{r}=$ $-0.82, P<0.01$, between $\mathrm{ADF}$ and LI and FA, respectively). Moreover, LI and FA contents of the MCM were higher (20 to 25\%) with AH-based diets than with CSbased diets (Table 2). Dietary CP did not explain a significant amount of variation in LI or FA.

\section{Fatty Acid Composition}

Identification. A set of nearly $50 \mathrm{FA}$ was obtained from the MCM using GLC. The ECL of FA ranged from 10 to 24 carbon units. The most easily and reliably identified FA were the 15 straight-saturated FA (evenand odd-chain FA) and the saturated FA presenting an iso (iso- $\mathrm{C}_{13: 0}$, iso- $\mathrm{C}_{14: 0}$, iso- $\mathrm{C}_{15: 0}$, iso- $\mathrm{C}_{16: 0}$, iso- $\mathrm{C}_{17: 0}$, and iso- $\mathrm{C}_{18: 0}$ ) or anteiso structure (anteiso- $\mathrm{C}_{15: 0}$, and anteiso$\mathrm{C}_{17: 0}$ ). The unsaturated FA were reliably identified by their ECL compared with standards, and by the number of double bonds. However, the position or geometry isomerism was less precise, particularly because peaks pooled several FA with the procedure applied. Among monoene FA, two had 16 atoms of carbon (cis- $\mathrm{C}_{16: 1 n-9}$ and cis- $\mathrm{C}_{16: 1 n-7}, \mathrm{ECL}=16.21$ and 16.27 , respectively), 
Table 3. Fatty acid (FA) composition of the microbial cell mass ( $\%$ of total FA).

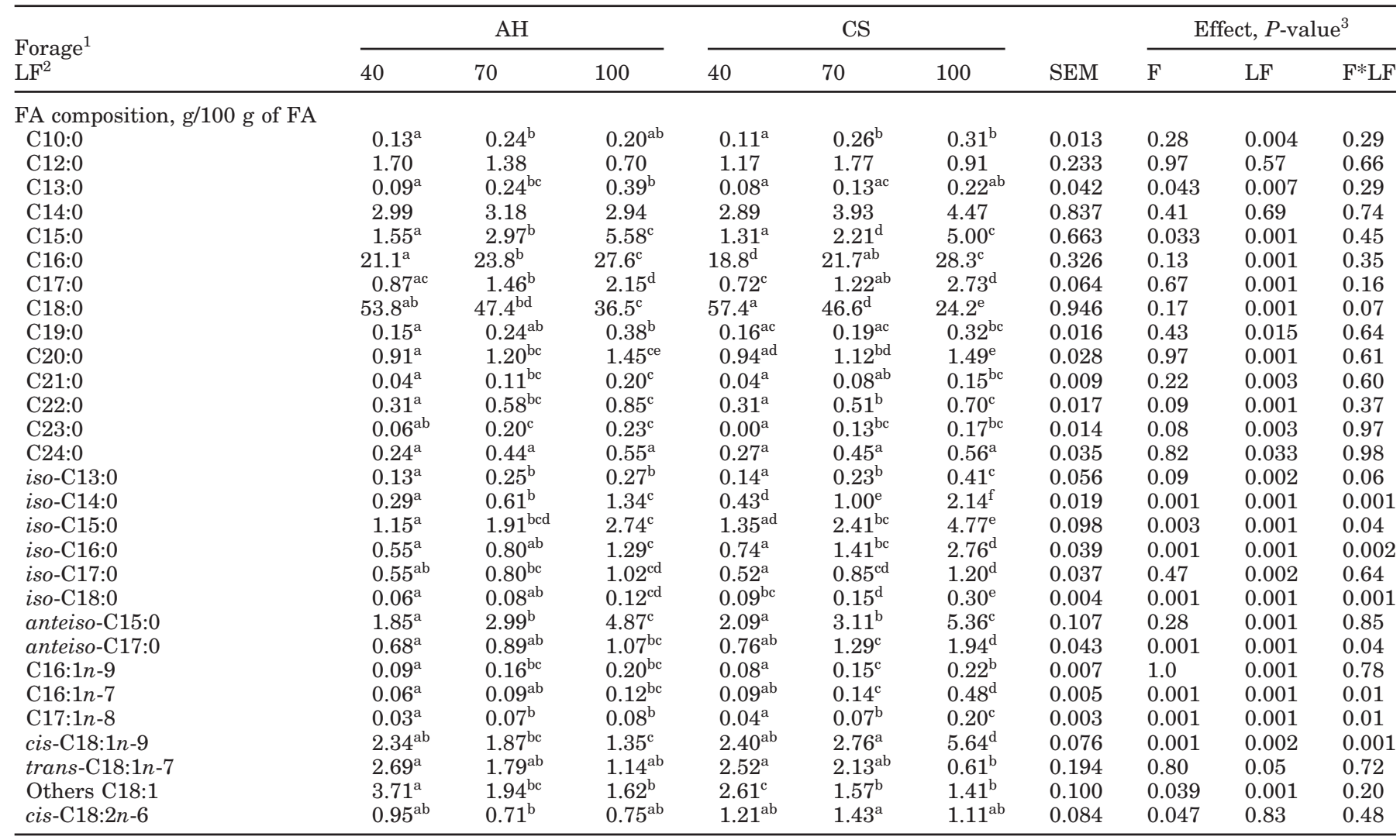

a,b,c,d,e,f Means within a row lacking a common superscript differ $(P<0.05)$.

${ }^{1} \mathrm{AH}=$ alfalfa hay, $\mathrm{CS}=$ Corn stover silage.

${ }^{2} \mathrm{LF}=$ level of forage (40,70, or $\left.100 \%\right)$.

${ }^{3} \mathrm{~F}=$ effect of type of forage (AH vs. CS), $\mathrm{LF}=$ effect of level of forage $(40,70$, or $100 \%), \mathrm{F} * \mathrm{LF}=$ interaction between $\mathrm{F}$ and $\mathrm{LF}$.

one had 17 atoms of carbon $\left(\right.$ cis $\left.-\mathrm{C}_{17: 1^{n}-8}, \mathrm{ECL}=17.25\right)$, and seven had 18 atoms of carbon $(\mathrm{ECL}=18.20,18.23$, $18.25,18.27,18.32,18.41$ and 18.64). The relationships between the last seven FA suggested the existence of two groups. The FA of ECL 18.20 and 18.27, which were positively correlated $(\mathrm{r}=0.59, P<0.05)$, likely were cis$\mathrm{C}_{18: 1 n-9}$ and cis- $\mathrm{C}_{18: 1 n-7}$. The second group was based on interpretation that $\mathrm{r}=0.62$ (18.25 vs. 18.23$), \mathrm{r}=0.60$ (18.25 vs. 18.32$), r=0.96$ (18.32 vs. 18.41$)$, and $r=$ 0.94 (18.32 vs. 18.64). Moreover, these FA tended to be negatively related to FA of ECL 18.20. These FA could

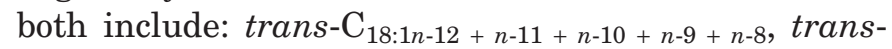
$\mathrm{C}_{18: 1 n-7}$, trans $-\mathrm{C}_{18: 1 n-6}$, trans $-\mathrm{C}_{18: 1 n-5+n-4}$, and trans $-\mathrm{C}_{18: 1 n-}$ 2. Only one polyenic FA was observed, which was identified as linoleic acid (cis-cis- $\mathrm{C}_{18: 2 n-6,}, \mathrm{ECL}=18.67$ ). Among the unidentified FA, four (ECL $=13.22,13.69,14.36$, and 15.65) presented the same base peak of 75 by electron impact, which together contributed to a low proportion of total FA $(0.10 \pm 0.01 \%)$. Three other unidentified FA had ECL of 15.88, 16.90, 19.01 and base peaks of 235,101 , and 249 , respectively. Together they contrib- uted $0.51 \pm 0.07 \%$ of total FA. A compound with an ECL of 16.90 seemed to correspond to phytanic FA (3,7,11,15-tetramethylhexadecanoic acid) based on similarity between ECL and electron fragmentation. There were no other branched-chain FA having one methyl substituent except iso- and anteiso-FA.

Lipid and FA composition of MCM. There were two major FA in MCM: $\mathrm{C}_{18: 0}$ and $\mathrm{C}_{16: 0}$. Twelve mean FA proportions ranged from 1 to $5 \%$, (Table 3): $\mathrm{C}_{12: 0}$, $\mathrm{C}_{14: 0}, \mathrm{C}_{15: 0}, \mathrm{C}_{17: 0}, \mathrm{C}_{20: 0}$, iso- $\mathrm{C}_{15: 0}$, iso- $\mathrm{C}_{16: 0}$, anteiso- $\mathrm{C}_{15: 0}$, anteiso- $\mathrm{C}_{17: 0}, \mathrm{C}_{18: 1 \mathrm{c} 9}, \mathrm{C}_{18: 1 t 11}$, and $\mathrm{C}_{18: 2 \mathrm{c} 9,12}$. The proportion of total monoenic FA was $7.2 \pm 0.4 \%$ of total FA. Total branched-chain FA (iso + anteiso) and of oddchain FA were $8.7 \pm 1.1 \%$, and $4.4 \pm 0.6 \%$, respectively. When FA content of MCM increased by $1 \%, \mathrm{C}_{18: 0}$ proportion increased by $2.9 \%$ of total FA (Figure 1 ) and $\mathrm{C}_{18: 0}$ proportion in MCM DM increased by $0.7 \mathrm{~g} / 100 \mathrm{~g}$.

$$
\begin{aligned}
& \mathrm{C}_{18: 0(\% / \Sigma \mathrm{FA})}=23.91+2.86 \mathrm{FA} ; \mathrm{r}^{2}=0.48, \mathrm{RSD}=7.1 \\
& \mathrm{C}_{18: 0(\% / \mathrm{DM})}=-1.72+0.70 \mathrm{FA} ; \mathrm{r}^{2}=0.92, \mathrm{RSD}=0.50 .
\end{aligned}
$$




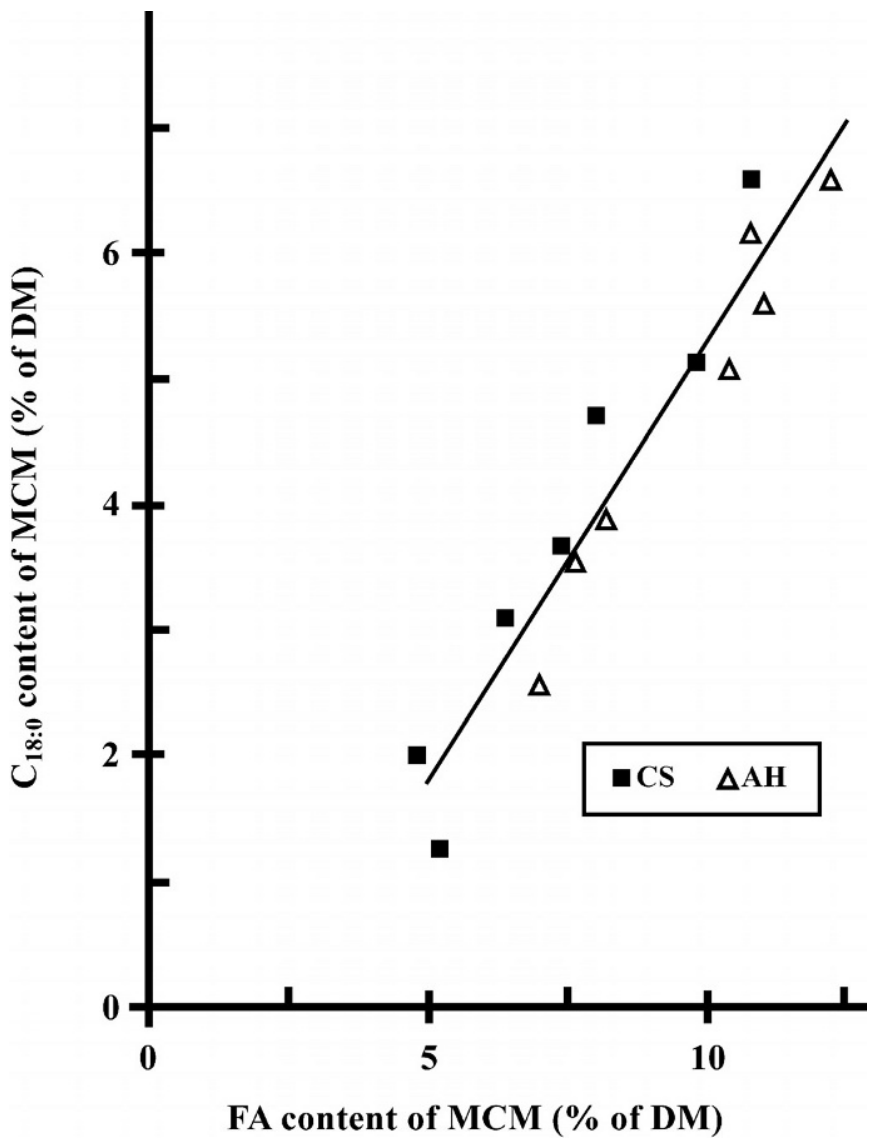

Figure 1. Relationship between $\mathrm{C}_{18: 0}$ content and total fatty acid (FA) content of the microbial cell mass (MCM), CS: corn stover; $\mathrm{AH}$ : alfalfa hay, $\mathrm{C}_{18: 0(\% \text { of DM })}=-1.72+0.70 \mathrm{FA}_{(\% \text { of DM }}, \mathrm{RSD}=0.50, \mathrm{r}^{2}=0.92$.

The $\mathrm{C}_{18: 0}$ was negatively correlated with all other linear saturated FA (even- and odd-chain FA) with the exception of $\mathrm{C}_{12: 0}$ and $\mathrm{C}_{14: 0}$, (Table 4). Likewise, stearic acid was negatively correlated with most of the monoenic FA $\left(\mathrm{C}_{16: 1 n-9}, \mathrm{C}_{16: 1 n-7}, \mathrm{C}_{17: 1 n-8}\right.$, cis- $\left.\mathrm{C}_{18: 1 n-9}\right)$, and with the branched-chain FA. These correlation coefficients were of similar magnitude for AH and CS. In contrast $\mathrm{C}_{18: 0}$ was positively correlated with the monoenic $\mathrm{FA}$ of ECL 18.23, 18.25, 18.32, 18.41, and $18.64(\mathrm{r}=0.66, P$ $=0.01 ; \mathrm{r}=0.63, P<0.05 ; \mathrm{r}=0.76, P<0.01 ; \mathrm{r}=0.72, P$ $<0.01$; and $\mathrm{r}=0.67, P<0.01$, respectively).

With AH-based diets the MCM had a total even-chain saturated FA proportion higher (76.7 vs. $73.0 \%, P<$ $0.01)$ than those of CS-based diets. The same tendency was noticed for total odd-chain saturated FA, (5.6 vs. $5.0 \%, P>0.05$ ) because of $\mathrm{C}_{13: 0}$ and $\mathrm{C}_{15: 0}$ (Table 3). Contrary to the latter FA, total branched-chain FA, total monoenic FA, and linoleic acid proportions were lower with AH- than with CS-based diets (8.8 vs. $11.8 \%$, 6.5 vs. $7.7 \%$, and 0.8 vs. $1.3 \%$, respectively). The difference in total monoenoic FA proportion between the

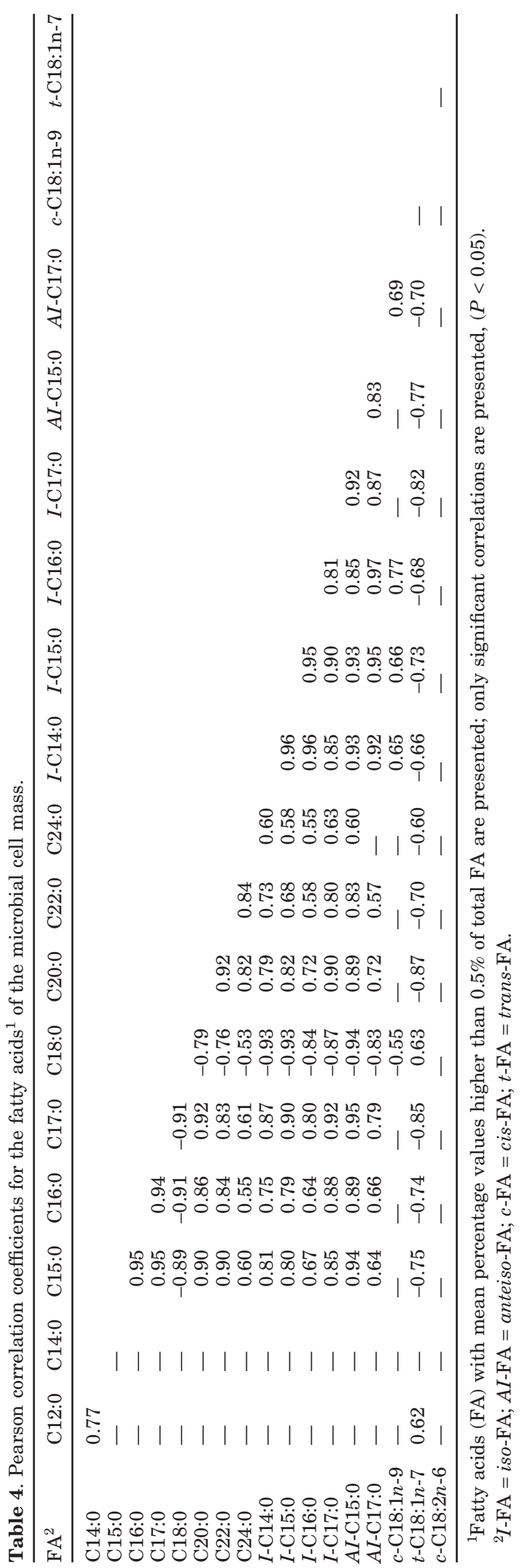

Journal of Dairy Science Vol. 86, No. 9, 2003 
MCM of AH- and CS-based diets resulted mainly from two fatty acids $\left(\mathrm{C}_{16: 1 n-7}\right.$ and cis- $\left.\mathrm{C}_{18: 1 n-9}\right)$. Four $\mathrm{C}_{18: 1}$ isomers separated with GLC $(\mathrm{ECL}=18.23$, 18.32, 18.42, and 18.64) were significantly higher in the MCM of AH- than CS-based diets. On a DM basis, differences between the FA proportions of MCM of diets based on the two forages were more pronounced than on a FA basis for straight saturated FA (even- or odd-chain FA, $+25.1 \%$, and $+34.7 \%$, respectively). Expressed on a DM basis, differences in MCM composition between diets based on the two forages were reduced for unsaturated FA and totally disappeared for branched-chain FA.

As LF increased from 40 to $100 \%$, the proportion of even-chain saturated FA decreased linearly from 81.5 to $65.8 \%$. This difference was due only to the $\mathrm{C}_{18: 0}$ proportion. In most cases, other even-chain $\mathrm{FA}$ proportion increased with increasing $\mathrm{LF}\left(\mathrm{C}_{10: 0}, \mathrm{C}_{16: 0}, \mathrm{C}_{20: 0}, \mathrm{C}_{22: 0}\right.$, and $\mathrm{C}_{24: 0}$; Table 3 ). There was a decrease of about $4 \%$ units in the $\mathrm{C} 18: 0$ percentage (as a percentage of total FA) per $10 \%$ units of forage:concentrate ratio increase, $\left(\mathrm{C}_{18: 0}=72.1-0.39 \mathrm{LF}, \mathrm{RSD}=4.52, \mathrm{r}^{2}=0.79\right)$, and there was an increase of about $1.2 \%$ units in the $\mathrm{C} 16: 0$ percentage per $10 \%$ units of forage:concentrate ratio increase $\left(\mathrm{C}_{16: 0}=14.7+0.12 \mathrm{LF}, \mathrm{RSD}=1.60, \mathrm{r}^{2}=0.75\right)$. With increasing $\mathrm{LF}$ ratio there was a linear increase in branched-chain and total odd-chain FA proportions (Table 3). Per 10\% units of forage:concentrate ratio increase, the increase in FA percentage was $0.8,0.6$, and $1 \%$ units, for the iso-, the anteiso- and the odd-chain FA percentages, respectively (iso-FA $=0.081 \mathrm{LF}, \mathrm{RSD}$ $=1.32, \mathrm{r}^{2}=0.94 ;$ anteiso-FA $=0.063 \mathrm{LF}, \mathrm{RSD}=0.60, \mathrm{r}^{2}$ $=0.98$; and odd-chain FA $=-1.54+0.096 \mathrm{LF}, \mathrm{RSD}=$ $\left.0.90, r^{2}=0.86\right)$. Increased LF seemed to decrease total monoenic FA proportions, mainly because of the $\mathrm{C}_{18: 1}$ isomers $(\mathrm{ECL}=18.23,18.25,18.32,18.41$, and 18.64), while proportions of other monoenic FA proportion increased $\left(\mathrm{C}_{16: 1 n-9}, \mathrm{C}_{16: 1 n-7}, \mathrm{C}_{17: 1 n-8}\right.$, cis- $\left.\mathrm{C}_{18: 1 n-9}\right)$. The linoleic acid proportion did not appear to be influenced by the LF. On a DM basis, differences in the MCM due to LF were higher than on a FA basis, for $\mathrm{C}_{18: 0}$ and for FA with ECL of $18.23,18.25,18.32,18.41$, and 18.64.

Variations in the FA profile of the MCM with level and type of forage were partly explained by dietary NDF content. Correlation coefficients between dietary NDF and FA percentages of the MCM were significant for $\mathrm{C}_{18: 0}$, total odd-chain $\mathrm{FA}$, total iso-, and total anteisoFA $(\mathrm{r}=-0.78, P<0.001 ; \mathrm{r}=0.56, P<0.05 ; \mathrm{r}=0.88, P$ $<0.001$; and $\mathrm{r}=0.82, P<0.001$, respectively). Those between dietary NDF and FA content of the MCM as a percentage of $\mathrm{DM}$ were only significant for $\mathrm{C}_{18: 0}$ and iso-FA ( $\mathrm{r}=-0.86, P<0.001 ; \mathrm{r}=0.71, P<0.01$, respectively). Dietary CP had no assumed effect on variation in the proportions of these FA.

\section{DISCUSSION}

\section{Fatty Acid Determination}

The FA profile of ruminal bacteria had similar concentrations of total unsaturated FA (monoenic and polyenic FA), and of total saturated odd-chain and branched-chain FA (8.3 and 13.1\%, respectively). Some of the differences in FA profile observed among studies could be due to methods used for separating and identifying FA. Moreover, the results of previous studies were seldom representative of the total microbial population but more often of liquid-associated bacteria (Czerkawski, 1976; Weisbjerg et al., 1992; Ferlay et al., 1993), which corresponded to only about one-third of total rumen bacteria (Legay-Carmier and Bauchart, 1989). Tetradecenoic acid was not detected in this study, but some authors reported relatively high concentrations of this acid (Tice et al., 1994; Hussein et al., 1995; Pantoja et al., 1996; Elliott et al., 1999). It could have been overestimated by contamination with branched-chain FA such as 13-methylpentadecanoic acid. In most of the above-mentioned studies, the content of saturated branched-chain FA was not indicated and the proportion of total identified FA varied from 73 to $100 \%$; therefore, a methodological bias might have led to erroneous values for the proportions of other FA. The current work confirmed previous observations that branched-chain FA were almost exclusively iso- and anteiso-branchedchain FA. Apart from some traces of FA derived from phytol, other branched-chain FA with straight-chain lengths of $14,15,16$, or 17 carbon atoms were not detected, in agreement with numerous results (Ifkovits and Ragheg, 1968; Viviani, 1970; Demeyer, 1973; Harfoot and Hazlewood, 1997).

\section{Variation in the Chemical Composition of Bacteria}

The mean values of the total $\mathrm{N}$ content of the MCM at the entrance of the duodenum were similar to those of Legay Carmier and Bauchart (1989), but in the low range of the numerous other values published in sheep and cattle (Hvelplund, 1986; Cecava et al., 1990; Clark et al., 1992; Hussein et al., 1995). As, in the present experiment, the technique of Legay Carmier and Bauchart (1989) was used to isolate bacteria, it was possible that a portion of the differences in $\mathrm{N}$ content of the MCM between our results and most others, may be attributed to differences in techniques utilized to isolate bacteria. In our study, the $\mathrm{N}$ content of bacterial DM did not appear to be closely related to the studied dietary factors, that was in accordance with most of the above-mentioned references. Yang et al. (2001) reported that the $\mathrm{N}$ content of bacteria varied with processing of cereals and forage, but not with $\mathrm{F}: \mathrm{C}$ ratio. 
The lipid and FA contents of MCM in the present study were similar to those reported by others for diets not supplemented with fat: Storm and Ørskov (1983), Bauchart et al. (1990), and O'Kelly and Spiers (1991). The FA:LI ratio, 0.56, was similar to that of LegayCarmier and Bauchart (1989) for a low-fat diet. This ratio appeared low, probably because of the high phospholipid content (30 to $40 \%$ ) for which this ratio was about 0.6 , and also the high nonsaponifiable matter content $(\geq 10 \%)$ of mixed rumen bacteria (Harfoot and Hazlewood, 1997).

The low $\mathrm{N}$ and lipid contents of MCM could be partly attributed to increased storage of polysaccharides, which was shown to be the most variable cell fraction (Hespell and Bryant, 1979). Moreover, there could be a problem isolating rumen microorganims free of plant particles using centrifugation. Duodenal feed particles of bacterial size could include lignified cell wall, chloroplast fragments, and ash, consequently decreasing the $\mathrm{N}$ and lipid contents of MCM. This bias could partly explain differences in FA compositions calculated as a percentage of total FA and as a percentage of DM.

Dietary NDF seemed to be the most important factor explaining variation in the lipid content of bacteria in diets not supplemented with fat. A similar influence of LF on microbial FA content was already reported by Sasaki et al. (2000); however, the range of dietary NDF in our study was larger than previously utilized. As usual, OM apparently digested in the rumen and total tract was negatively, and closely, related to dietary NDF (Archimède et al., 1995). Storage of energy in lipids could be greater than in carbohydrates, particularly for attached bacteria. This observation is not consistent with results of Czerkawski (1976) who stated that the increase in bacterial lipid content was linked with an increase in dietary concentrates by their higher lipid content. Nevertheless, dietary NDF had a moderate effect on the lipid content of ruminal bacteria that was often confounded with dietary lipid content (Klusmeyer and Clark, 1991; Weisbjerg et al., 1992; Tice et al., 1994; Hussein et al., 1995; Pantoja et al., 1996; Christensen et al., 1998; Elliott et al., 1999).

\section{Changes in Fatty Acid Composition}

Supplementation of animal or plant fat alters the FA composition of MCM, particularly of long-chain unsaturated FA depending on the type of dietary fat supplement (Sauvant and Bas, 2001). With diets not supplemented with fats, the unsaturated FA contents reported in the literature are also variable. In the present experiment, the unsaturated FA content of bacteria appeared to be low with a high forage level (70 and 100\%), in accordance with results from forage based diets (O’Kelly and Spiers, 1991).

The decrease in the proportion of stearic acid in MCM as LF increased is consistent with the results of Sasaki et al. (2000), but not consistent with those of Kucuk et al. (2001) with soybean oil-supplemented diets. With diets not supplemented with fat, the higher their NDF content the lower the stearic acid content of bacteria. These results suggest that a higher diet energy density increased the yield of energy stored by ruminal microorganisms as FA, in the same manner that it increased the concentration of bacteria in the rumen (cf. review of Dehority and Orpin, 1988). In this experiment, dietary LF or NDF content apparently could have affected the efficiency of microbial growth. This conclusion is supported by the results of Archimède et al. (1996), who reported that microbial efficiency tended be affected, and by those of Weimer et al. (1999), who indicated that the ruminal cellulolytic bacteria population tended to increase, with higher NDF or forage contents of diets. Moreover, a shift in the distribution of rumen bacteria species was reported by Dehority and Orpin (1988) as dietary NDF varied. This could have influence FA composition because of the large differences in FA composition among strains of rumen bacteria (Minato et al., 1988).

Increases in trans- $\mathrm{C}_{18: 1} \mathrm{FA}$ in MCM for goats fed a high level of concentrate were in agreement with previous research. Kalscheur et al. (1997a) found that cows fed a diet with a $25 \%$ forage had twofold greater duodenal trans- $\mathrm{C}_{18: 1} \mathrm{FA}$ flows and $87 \%$ greater concentrations of trans- $\mathrm{C}_{18: 1} \mathrm{FA}$ in milk than cows fed a $60 \%$ forage diet. In goat milk the concentration of trans- $\mathrm{C}_{18: 1} \mathrm{FA}$ was $38 \%$ greater with a $30 \%$ of $\mathrm{AH}$ diet than with a $60 \% \mathrm{AH}$ diet. These increases in concentration of trans$\mathrm{C}_{18: 1} \mathrm{FA}$ in the duodenal digesta and milk probably resulted from incomplete biohydrogenation of dietary FA which is dependent, in part, on the ruminal microbial population.

Differences in NDF or forage contents between diets also induced variation in the branched-chain FA percentage and content of bacteria. This confirms preliminary observations (Dewhurst et al., 2000, 2002; Vlaeminck et al., 2002). Variation in the dietary energy content or fat content had pronounced effects on the amount of free FA stored in lipid droplets in bacteria but had less effect on polar lipid content (Bauchart et al., 1990). Bacteria were characterized using FA synthetases, specific either for straight-chain FA or for branched-chain FA (Kaneda, 1991). Acetyl-CoA was a less good substrate than short branched-chain FA for growth of some species of ruminal bacteria in which branched-chain FA synthetase has a preference for branched short-chain carboxylic acids to synthesize the 
related long-chain FA, as demonstrated previously with labelled $\left({ }^{14} \mathrm{C}\right)$ branched short-chain carboxylic acids $\left({ }^{14} \mathrm{C}\right.$-isovalerate, ${ }^{14} \mathrm{C}$-isobutyrate, and ${ }^{14} \mathrm{C}$-valine; Allison and Bryant, 1961; Tweedie et al., 1966). The high content of odd-chain and branched-chain FA, with an iso- or an anteiso-structure indicated their importance to FA synthesis in the rumen. These branched-chain FA could be considered as hydrogen captors made up during anaerobic fermentation. The use of branched short-chain carbolylic acids for the synthesis of branched-chain FA contributed to energy conservation. The odd-chain FA and the isoFA with $\mathrm{n}$ atoms of carbon had a melting point 1 to $2^{\circ} \mathrm{C}$ lower than that of straightchain FA with $n-1$ atoms of carbon (Gunstone et al., 1994). However, the existence of a methyl substituent in an anteiso position on an even-chain FA lowered the melting point by about 25 to $30^{\circ} \mathrm{C}$ (Gunstone et al., 1994). Thus, incorporating either odd-chain or branched-chain FA, of iso- or anteiso-structure, into bacterial membranes could act in conjunction with decreased mean chain length of saturated FA to compensate for a deficiency of available unsaturated FA for membrane function and help maintain of lipid fluidity.

\section{CONCLUSIONS}

Our results showed that, independently from fat supplementation, diet composition can alter the content and composition of ruminal bacteria FA. The bacterial FA content can be altered by LF or NDF content. High LF favored the synthesis of branched-chain FA in rumen bacteria. These FA could play a role in hydrogen transfer, conserving energy for the host animal. Knowledge of the chemical composition of rumen bacteria is essential both to accurately estimate nutrient supplies to the host animal and to better understand the effects of bacterial constituents on the FA composition of body tissues and milk fat.

\section{ACKNOWLEDGMENTS}

The authors thank M. Murphy (Department of Animal Sciences, Univ. of Illinois) for the fruitful discussions on the topic and for assistance in the preparation of the manuscript.

\section{REFERENCES}

Allison, M. J., and M. P. Bryant. 1961. The metabolic fate of isovalerate in Ruminococcus flavefaciens. J. Dairy Sci. 44:1203. (Abstr.).

Alonso, L., J. Fontecha, L. Lozada, M. J. Fraga, and M. Juárez. 1999. Fatty acid composition of caprine milk: major, branched-chain, and trans fatty acids. J. Dairy Sci. 82:878-884.

Archimède, H., D. Sauvant, J. Hervieu, C. Poncet, and M. Dorléans. 1995. Digestive interactions in ruminants: relationships between whole tract and stomach evaluation. Anim. Feed Sci. Technol. 54:327-340.
Archimède, H., D. Sauvant, J. Hervieu, F. Ternois, and C. Poncet. 1996. Effects of the nature of roughage and concentrate and their proportion on ruminal characteristics on non lactating goats, consequences on digestive interactions. Anim. Feed Sci. Technol. $58: 267-282$

Bae, G. S., M. B. Chang, W. J. Maeng, R. J. Dewhurst, D. R. Davies, and R. J. Merry. 2000. Variation in the concentrations of oddchain fatty acids in rumen bacteria. Page 32 in Proc. 25th Conf. Rumen Function, Chicago, IL.

Bas, P., and P. Morand-Fehr. 2000. Effect of nutritional factors on fatty acid composition of lamb fat deposits. Livest. Prod. Sci. 64:61-79.

Bauchart, D., F. Legay-Carmier, M. Doreau, and B. Gaillard. 1990. Lipid metabolism of liquid-associated and solid-adherent bacteria in rumen contents of dairy cows offered lipid-supplemented diets. Br. J. Nutr. 63:563-578.

Cecava, M. J., N. R. Merchen, L. C. Gay, and L. L. Berger. 1990. Composition of ruminal bacteria harvested from steers as influenced by dietary energy level, feeding frequency, and isolation techniques. J. Dairy Sci. 73:2480-2488.

Christensen, R. A., J. H. Clark, J. K. Drackley, and S. A. Blum. 1998. Fatty acid flow to the duodenum and in milk from cows fed diets that contained fat and nicotinic acid. J. Dairy Sci. 81:1078-1088.

Clark, J. H., T. H. Klusmeyer, and M. R. Cameron. 1992. Microbial protein synthesis and flows of nitrogen fractions to the duodenum of dairy cows. J. Dairy Sci. 75:2304-2323.

Czerkawski, J. W. 1976. Chemical composition of microbial matter in the rumen. J. Sci. Food. Agric. 27:621-632.

Dehority, B. A., and C. G. Orpin. 1988. Development of, and natural fluctuations in, rumen microbial populations. Pages 151-183 in The Rumen Microbial Ecosystem. P. N. Hobson, ed. Elsevier Science Publishers, London.

Demeyer, D. 1973. Lipidstoffwechsel im Pansen. [Variation in the lipid content of the rumen]. Pages 209-234 in Biologie und Biochemie der Mikrobiellen Verdauung. D. Giesecke, and H. Henderickx, ed. BLV Verslaggesellschft; Munchen, Germany.

Demeyer, D., and M. Doreau. 1999. Targets and procedures for altering ruminant meat and milk lipids. Proc. Nutr. Soc. 58:593-607.

Dewhurst, R. J., J. K. S. Tweed, and G. B. Williams. 2000. Variation in the concentrations of odd-chain fatty acids in milk. Page 31 in Proc. 25th Conf. Rumen Function, Chicago, IL

Dewhurst, J., J. M. Moorby, J. Danelón, and J. K. Tweed. 2002. Effect of diet forage:concentrate ratio on odd-chain fatty acids in milk from Holstein-Friesian cows. J. Dairy Sci. 85(Suppl. 1):318. (Abstr.)

Duncan, W. R. H., and G. A. Garton. 1978. Differences in the proportions of branched-chain fatty acids in subcutaneous triacylglycerols of barley-fed ruminants. Br. J. Nutr. 40:29-33.

Elliott, J. P., J. K. Drackley, A. D., Beaulieu, C. G. Aldrich, and N. R. Merchen. 1999. Effects of saturation and esterification of fat on site and extent of digestion in steers: Digestion of fatty acids, triglycerides, and energy. J. Anim. Sci. 77:1919-1929.

Ferlay, A., J. Chabrot, Y. Elmeddah, and M. Doreau. 1993. Ruminal balance and intestinal digestion by dairy cows fed calcium salts of rapeseed oil fatty acids or rapeseed oil. J. Anim. Sci. $71: 2237-2245$

Gunstone, F. D., J. L. Harwood, and F.B. Padley. (1994). Dictionary in The Lipid Handbook. 2nd ed. F. D. Gunstone, J. L. Harwood, and F.B. Padley, eds. Chapman and Hall, London.

Harfoot, C. G. and G. P. Hazlewood. 1997. Lipid metabolism in the rumen. Pages 382-426 in The Rumen Microbial Ecosystem. P. N. Hobson, and C. S. Stewart, ed. Blackie Academic \& Professional, Chapman \& Hall, London.

Hespell, B., and M. P. Bryant. 1979. Efficiency of rumen microbial growth: Influence of some theorical and experimental factors on $\mathrm{Y}_{\text {ATP. J. Anim. Sci. 49:1640-1659. }}$

Hussein, H. S., N. R. Merchen, and G. C. Fahey, Jr. 1995. Composition of ruminal bacteria harvested from steers as influenced by dietary forage level and fat supplementation. J. Anim. Sci. 73:2469-2473.

Hvelplund, T. 1986. The influence of diet on nitrogen and amino acid content of mixed rumen bacteria. Acta Agric. Scand. 36:325-331. 
Ifkovitis, R. W., and H. S. Ragher. 1968. Cellular fatty acid composition and identification of rumen bacteria. Appl. Microbiol. 16:1406-1415.

Kalscheur, K. F., B. B. Teter, L. S. Piperova, and R. A. Erdman. 1997a. Effect of dietary forage concentration and buffer addition on duodenal flow of trans-C18:1 fatty acids and milk fat production in dairy cows. J. Dairy Sci. 80:2104-2114.

Kalscheur, K. F., B. B. Teter, L. S. Piperova, and R. A. Erdman. 1997b. Effect of fat source on duodenal flow of trans-C18:1, fatty acids and milk fat production in dairy cows. J. Dairy Sci. 80:2115-2126.

Kaneda, T. 1991. Iso- and anteiso-fatty acids in bacteria: Biosynthesis, function, and taxonomic significance. Microbiol. Rev. 55:288-302.

Kelly, M. L., E. S. Kolver, D. E. Bauman, M. E. Van Amburgh, and L. D. Muller. 1998. Effect of intake of pasture on concentrations of conjugated linoleic acid in milk of lactating cows. J. Dairy Sci. $81: 1630-1636$.

Klusmeyer, T. H., and J. H. Clark. 1991. Effects of dietary fat and protein on fatty acid flow to the duodenum and in milk produced by dairy cows. J. Dairy Sci. 74:3055-3067.

Kucuk, O., B. W. Hess, P. A. Ludden, and D. C. Rule. 2001. Effect of forage:concentrate ratio on ruminal digestion and duodenal flow of fatty acids in ewes. J. Anim. Sci. 79:2233-2240.

LeDoux, M., A. Rouzeau, P. Bas, and D. Sauvant. 2002. Occurrence of trans-C18:1 fatty acid isomers in goat milk: Effect of two dietary regimens. J. Dairy Sci. 85:190-197.

Legay-Carmier, F., and D. Bauchart. 1989. Distribution of bacteria in the rumen contents of dairy cows given a diet supplemented with soya-bean oil. Br. J. Nutr. 61:725-740.

Minato, H., S. Ishibashi, and T. Hamaoka. 1988. Cellular fatty acid and sugar composition of representative strains of rumen bacteria. J. Gen. Appl. Microbiol. 34:303-319.

Miwa, T. K., K. L. Mikolajzack, F. R. Earle, and I. A. Wolff. 1960. Gas chromatographic characterization of fatty acids. Identifications of constants for mono and dicaboxylic methyl esters. Anal. Chem. $32: 1729-1742$.

Moore, J. H., and W. W. Christie. 1984. Digestion, absorption and transport of fats in ruminant animals. Pages 123-149 in Fats in Animal Nutrition. J. Wieseman, ed. Butterworths, London.

O'Kelly, J. C., and W. G. Spiers. 1991. Influence of host diet on the concentrations of fatty acids in rumen bacteria from cattle. Aust. J. Agric. Res. 42:243-252.

Pantoja, J., J. L. Firkins, M. L. Eastridge, and B. H. Hull. 1996. Fatty acid digestion in lactating dairy cows fed fats varying in degree of saturation and different fiber sources. J. Dairy Sci. 79:575-584.
Parodi, P. W. 1977. Conjugated octadecadienoic acids in milk fat. J. Dairy Sci. 60:1550-1553.

Parodi, P. W. 1999. Conjugated linoleic acid and other anticarcinogenic agents of bovine milk fat. J. Dairy Sci. 82:1339-1349.

SAS User's Guide: Statistics, Version 6 Edition. 1987. SAS Inst., Inc., Cary, NC.

Sasaki, H., T. Takahashi, and T. Kayaba. 2000. [Effects of the different ratios of concentrate and roughage on the concentration and composition of long chain fatty acids of rumen microorganisms and microorganisms free-liquor in sheep]. Anim. Sci. J. 71:J26-J38.

Sauvant D., and P. Bas. 2001. La digestion des lipides chez les ruminants. [Lipid digestion in ruminants]. INRA Prod. Anim. 14:303-310.

Stanton, C., F. Lawless, G. Kjellmer, D. Harrington, R. Devery, J. F. Connoly, and J. Murphy. 1997. Dietary influences on bovine milk cis-9, trans-11-conjugated linoleic acid content. J. Food Sci. 62:1083-1086.

Storm, E., and E. R. Ørskov. 1983. The nutritive value of rumen microorganisms in ruminants. 1. Large-scale isolation and chemical composition of rumen micro-organisms. Br. J. Nutr. 50:463-470.

Tice, E. M., M. L. Eastridge, and J. L. Firkins. 1994. Raw soybeans and roasted soybeans of different particle sizes. 2. Fatty acid utilization by lactating cows. J. Dairy Sci. 77:166-180.

Tweedie, J. W., M. G. Rumsby, and J. C. Hawke. 1966. Studies on rumen metabolism. V. Formation of branched long chain fatty acids in cultures of rumen bacteria. J. Sci. Food. Agric. 17:241244.

Viviani, R. 1970. Metabolism of long chain fatty acids in the rumen. Adv. Lipid Res. 8:267-346.

Vlaeminck, B. M., H. Bruinenberg, V. Fievez, K. Raes, and D. Demeyer. 2002. Effect of crude fibre content in grass silage on milk odd-chain fatty acids. Reprod. Nutr. Dev. 42(Suppl. 1):71. (Abstr.)

Weimer, P. J., G. C. Waghorn, C. L. Odt, and D. R. Mertens. 1999 Effect of diet on populations of three species of ruminal cellulolytic bacteria in lactating dairy cows. J. Dairy Sci. 82:122-134.

Weisbjerg, M. R., C. F. Børsting, and T. Hvelplund. 1992. The influence of tallow on rumen metabolism microbial biomass synthesis and fatty acid composition of bacteria and protozoa. Acta Agric. Scand., Sect. A, Anim. Sci. 42:138-147.

Yang, W. Z., K. A. Beauchemin, and L. M. Rode. 2001. Effect of dietary factors on distribution and chemical composition of liquid- or solid-associated bacterial populations in the rumen of dairy cows. J. Anim. Sci. 79:2736-2746. 